Prepared in cooperation with the Washington State Department of Health

\title{
Estimating the Probability of Elevated Nitrate Concentrations in Ground Water in Washington State
}

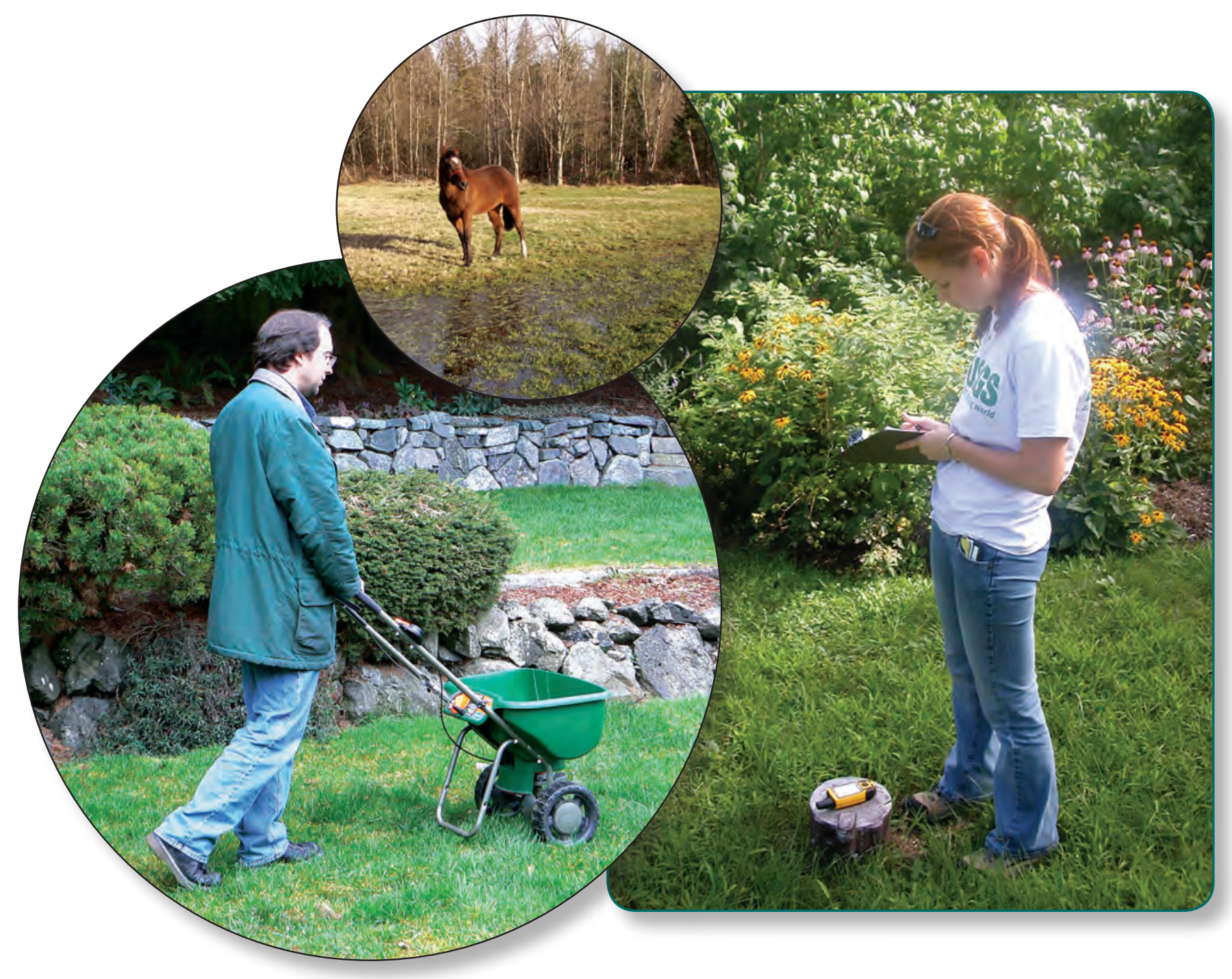

Scientific Investigations Report 2008-5025 


\section{Cover:}

Top: Photograph showing example of agricultural land use. (Photograph taken by Anthony Grillo, private citizen, February 26, 2008.)

Bottom left: Photograph showing fertilizer being applied in a residential area.

(Photograph taken by Lonna Frans, U.S. Geological Survey, February 26, 2008.)

Bottom right: Photograph showing USGS scientist determining a well location.

(Photograph taken by U.S. Geological Survey staff.) 


\section{Estimating the Probability of Elevated Nitrate Concentrations in Ground Water in Washington State}

By Lonna M. Frans

Prepared in cooperation with the Washington State Department of Health

Scientific Investigations Report 2008-5025 


\section{U.S. Department of the Interior DIRK KEMPTHORNE, Secretary}

\section{U.S. Geological Survey \\ Mark D. Myers, Director}

\section{U.S. Geological Survey, Reston, Virginia: 2008}

For product and ordering information:

World Wide Web: http://www.usgs.gov/pubprod

Telephone: 1-888-ASK-USGS

For more information on the USGS--the Federal source for science about the Earth, its natural and living resources, natural hazards, and the environment:

World Wide Web: http://www.usgs.gov

Telephone: 1-888-ASK-USGS

Any use of trade, product, or firm names is for descriptive purposes only and does not imply endorsement by the U.S. Government.

Although this report is in the public domain, permission must be secured from the individual copyright owners to reproduce any copyrighted materials contained within this report.

Suggested citation:

Frans, L.M., 2008, Estimating the probability of elevated nitrate concentrations in ground water in Washington State: U.S. Geological Survey Scientific Investigations Report 2008-5025, 22 p. 


\section{Contents}

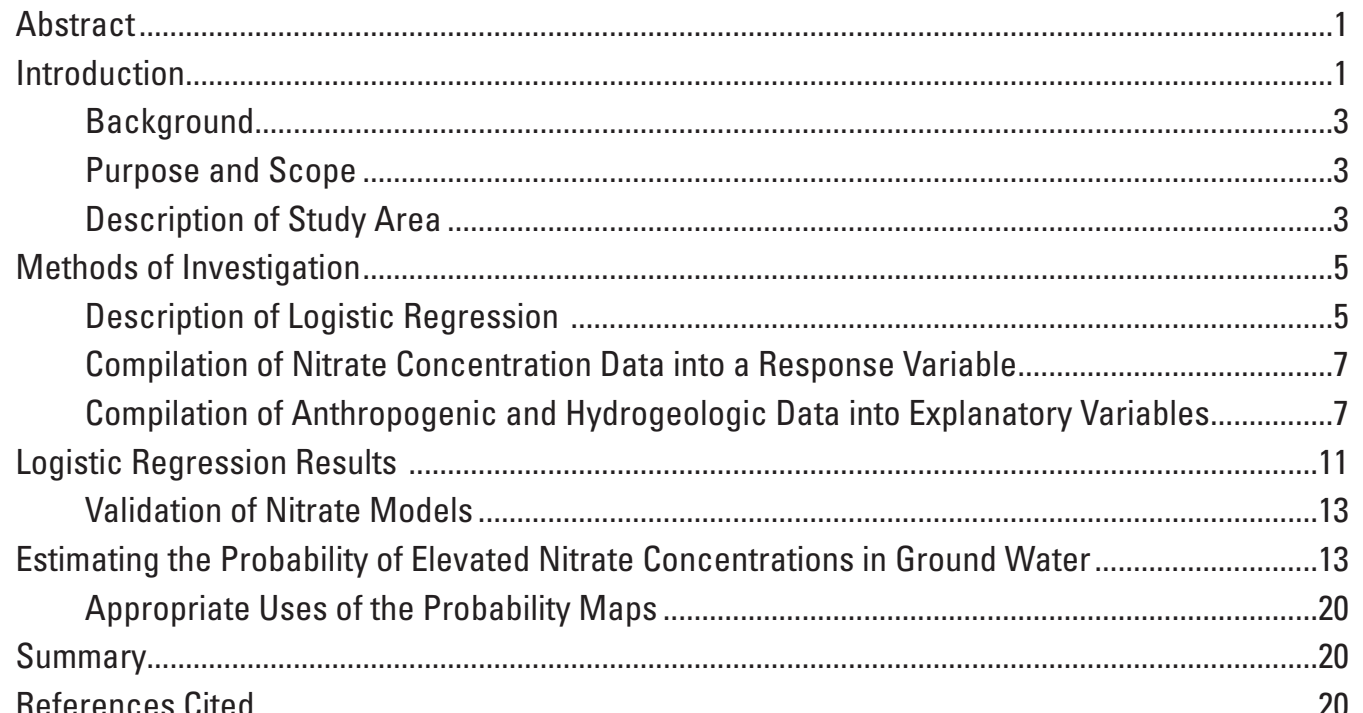

\section{Figures}

Figure 1. Map showing location of counties and major cities in Washington .............. 2

Figure 2. Map showing hydrogeomorphic regions in Washington $\ldots \ldots \ldots \ldots \ldots \ldots \ldots \ldots \ldots .4$

Figure 3. Map showing nitrate concentrations in water from wells in Washington from the Washington State Department of Health database $(1995-2006)$............. 8

Figure 4. Graph showing nitrate concentrations in ground-water samples collected in hydrogeomorphic regions in Washington from the Washington State

Department of Health database (1995-2006)

Figure 5. Map showing nitrate concentrations in water from wells in Washington from the U.S. Geological Survey and Washington State Department of Ecology databases (1995-2006)...

Figure 6. Graph showing McFadden's rho squared from relations of amount of nitrogen application and percentage of agricultural, urban, and undeveloped lands within circular buffers around wells with nitrate concentrations greater than 2 milligrams per liter in ground water in Washington

Figure 7. Graphs showing percentage of actual nitrate concentrations greater than 2 milligrams per liter (mg/L) and the estimated probability of nitrate concentrations greater than $2 \mathrm{mg} / \mathrm{L}$ in the calibration dataset

Figure 8. Graphs showing percentage of actual nitrate concentrations greater than 2 milligrams per liter $(\mathrm{mg} / \mathrm{L})$ and the estimated probability of nitrate concentrations greater than $2 \mathrm{mg} / \mathrm{L}$ in the validation dataset 


\section{Figures-Continued}

Figure 9. Maps showing probability of detecting nitrate concentrations greater than 2 milligrams per liter in ground water at a depth of 145 feet below land surface for the two logistic regression models with and without hydrogeomorphic regions, Washington

Figure 10. Maps showing probability of detecting nitrate concentrations greater than 2 milligrams per liter in ground water at a depth of 145 feet below land surface for the two logistic regression models with and without hydrogeomorphic regions, Puget Sound region, Washington

Figure 11. Maps showing depth to which wells need to be drilled for at least a 90-percent probability of detecting a nitrate concentration less than 2 milligrams per liter in ground water for the logistic regression model without hydrogeomorphic regions, State of Washington and Puget lowlands

\section{Tables}

Table 1. Summary of anthropogenic and natural explanatory variables used for model development

Table 2. Regression coefficients and individual $p$-values of independent variables for the two logistic regression models with and without hydrogeomorphic regions that were signific antly related with nitrate concentrations greater than 2 milligrams per liter in ground water in Washington

Table 3. Statistical results from models that estimate the probability of nitrate concentrations exceeding 2 milligrams per liter in ground water in Washington ... 11 


\section{Conversion Factors and Datums}

Conversion Factors

Inch/Pound to SI

\begin{tabular}{|c|c|c|}
\hline Multiply & By & To obtain \\
\hline \multicolumn{3}{|c|}{ Length } \\
\hline inch (in.) & 2.54 & centimeter $(\mathrm{cm})$ \\
\hline inch (in.) & 25.4 & millimeter (mm) \\
\hline foot (ft) & 0.3048 & meter $(\mathrm{m})$ \\
\hline \multicolumn{3}{|c|}{ Area } \\
\hline acre & 0.004047 & square kilometer $\left(\mathrm{km}^{2}\right)$ \\
\hline square mile $\left(\mathrm{mi}^{2}\right)$ & 2.590 & square kilometer $\left(\mathrm{km}^{2}\right)$ \\
\hline \multicolumn{3}{|l|}{ SI to Inch/Pound } \\
\hline Multiply & By & To obtain \\
\hline \multicolumn{3}{|c|}{ Length } \\
\hline meter $(\mathrm{m})$ & 3.281 & foot (ft) \\
\hline kilometer (km) & 0.6214 & mile (mi) \\
\hline kilometer (km) & 0.5400 & mile, nautical (nmi) \\
\hline meter $(\mathrm{m})$ & 1.094 & yard $(y d)$ \\
\hline \multicolumn{3}{|c|}{ Area } \\
\hline square kilometer $\left(\mathrm{km}^{2}\right)$ & 247.1 & acre \\
\hline square kilometer $\left(\mathrm{km}^{2}\right)$ & .0386 & square mile $\left(\mathrm{mi}^{2}\right)$ \\
\hline
\end{tabular}

Temperature in degrees Celsius $\left({ }^{\circ} \mathrm{C}\right)$ may be converted to degrees Fahrenheit $\left({ }^{\circ} \mathrm{F}\right)$ as follows:

$$
{ }^{\circ} \mathrm{F}=\left(1.8 \mathrm{x}^{\circ} \mathrm{C}\right)+32 .
$$

Temperature in degrees Fahrenheit $\left({ }^{\circ} \mathrm{F}\right)$ may be converted to degrees Celsius $\left({ }^{\circ} \mathrm{C}\right)$ as follows:

${ }^{\circ} \mathrm{C}=\left({ }^{\circ} \mathrm{F}-32\right) / 1.8$.

Concentrations of chemical constituents in water are given either in milligrams per liter (mg/L) or micrograms per liter $(\mu \mathrm{g} / \mathrm{L})$.

Datums

Vertical coordinate information is referenced to the North American Vertical Datum of 1988 (NAVD 88).

Horizontal coordinate information is referenced to the North American Datum of 1983 (NAD 83).

Altitude, as used in this report, refers to distance above the vertical datum. 
This page intentionally left blank. 


\title{
Estimating the Probability of Elevated Nitrate Concentrations in Ground Water in Washington State
}

\author{
By Lonna M. Frans
}

\section{Abstract}

Logistic regression was used to relate anthropogenic (manmade) and natural variables to the occurrence of elevated nitrate concentrations in ground water in Washington State. Variables that were analyzed included well depth, groundwater recharge rate, precipitation, population density, fertilizer application amounts, soil characteristics, hydrogeomorphic regions, and land-use types. Two models were developed: one with and one without the hydrogeomorphic regions variable. The variables in both models that best explained the occurrence of elevated nitrate concentrations (defined as concentrations of nitrite plus nitrate as nitrogen greater than 2 milligrams per liter) were the percentage of agricultural land use in a 4-kilometer radius of a well, population density, precipitation, soil drainage class, and well depth. Based on the relations between these variables and measured nitrate concentrations, logistic regression models were developed to estimate the probability of nitrate concentrations in ground water exceeding 2 milligrams per liter. Maps of Washington State were produced that illustrate these estimated probabilities for wells drilled to 145 feet below land surface (median well depth) and the estimated depth to which wells would need to be drilled to have a 90-percent probability of drawing water with a nitrate concentration less than 2 milligrams per liter. Maps showing the estimated probability of elevated nitrate concentrations indicated that the agricultural regions are most at risk followed by urban areas. The estimated depths to which wells would need to be drilled to have a 90-percent probability of obtaining water with nitrate concentrations less than 2 milligrams per liter exceeded 1,000 feet in the agricultural regions; whereas, wells in urban areas generally would need to be drilled to depths in excess of 400 feet.

\section{Introduction}

Ground water is a significant source of drinking water in Washington State (fig. 1), where more than 60 percent of the population uses ground water for domestic needs (Ron Lane, U.S. Geological Survey, oral commun., August 2007). Nitrate concentrations in ground water are elevated in parts of the State as a result of various land-use practices, including fertilizer application, dairy operations and ranching, and septic-system use (Williamson and others, 1998; Ebbert and others, 2000). Consumption of water with elevated nitrate concentrations is linked to methemoglobinemia, or "blue baby" disorder, a potentially fatal condition caused by low oxygen levels in the blood of infants (Fewtrell, 2004) and spontaneous abortion among some women (Centers for Disease Control and Prevention, 1996). High nitrate concentrations also have been linked to bladder and ovarian cancer (Weyer and others, 2001) and non-Hodgkin's lymphoma (Ward and others, 1996).

To help assure the quality of the State's drinking-water supply, the Washington State Department of Health (WDOH) requires that public-supply water systems regularly measure nitrate concentrations. However, such testing is only required of public-supply systems and, as a result, citizens and public health officials have only limited information about the potential exposure to elevated nitrate concentrations for people whose primary drinking-water sources are private wells. To assist public health officials, WDOH asked the U.S. Geological Survey (USGS) to develop maps that show the relation between elevated nitrate concentrations and the locations and depths of wells. This information could be used to help estimate exposure to nitrate in drinking water in areas without measurements of nitrate concentrations in ground water. 


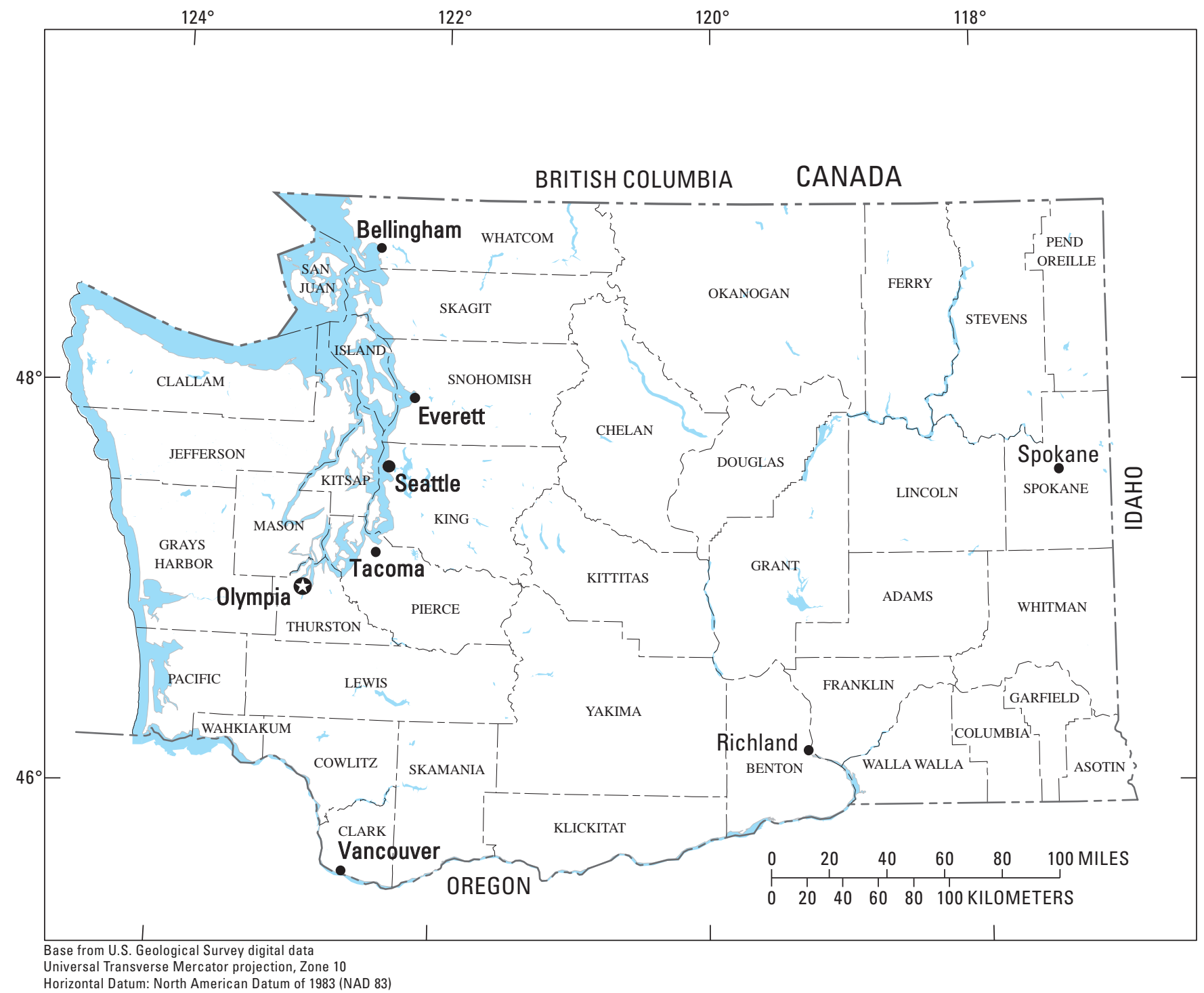

Figure 1. Location of counties and major cities in Washington. 


\section{Background}

Ground-water vulnerability maps are designed to estimate the potential for contamination of ground water in an area based on anthropogenic and hydrogeologic factors. Multiple definitions exist for the term "ground-water vulnerability" depending on the research objectives. For this study, we use the definition from the National Research Council (1993), which states that ground-water vulnerability to contamination is

“...the tendency or likelihood for contaminants to reach a specified position in the ground-water system after introduction at some location above the uppermost aquifer."

The National Research Council (1993) refined the definition on the basis of whether the assessment was contaminant specific, defined as "specific vulnerability," or for any contamination in general, "intrinsic vulnerability."

Three previous studies, Tesoriero and others (1998), Frans (2000), and Nolan and others (2002), partially estimated ground-water vulnerability of the State of Washington to nitrate contamination. Tesoriero and others (1998) developed a logistic regression model to estimate the probability of nitrate contamination exceeding $3 \mathrm{mg} / \mathrm{L}$ in the Puget lowland. Well depth, surficial geology, and land use (forest, urban, and agriculture) in a 3.2-km radius of a well were identified as the significantly related variables.

In Frans (2000), logistic regression models were developed to estimate the probability of nitrate contamination exceeding 3 and $10 \mathrm{mg} / \mathrm{L}$ for Grant, Franklin, and Adams Counties in eastern Washington. In those models, well casing depth, fertilizer application amounts, and the mean soil hydrologic group were identified as the significantly related variables.

Nolan and others (2002) developed a logistic regression model to estimate the probability of nitrate contamination exceeding $4 \mathrm{mg} / \mathrm{L}$ in predominantly shallow, recently recharged ground waters of the conterminous United States. The significantly related variables were nitrogen fertilizer loading, percentage of cropland as pasture, natural log of human population density, percentage of well-drained soils, depth to seasonally high water table, and presence or absence of unconsolidated sand and gravel aquifers. Although this model was applied to the conterminous United States, few data used to calibrate the model were from the State of Washington (Nolan and others, 2002).

\section{Purpose and Scope}

This report presents the results of an analysis relating anthropogenic and natural factors to the occurrence of elevated nitrate concentrations in ground water of Washington State. The probability of elevated nitrate concentrations at a particular location was estimated using a logistic regression model. The logistic regression model was entered into a geographic information system (GIS) to produce maps that display the probability of elevated nitrate concentrations throughout Washington State. In this report, nitrate concentration refers to the concentration of nitrite plus nitrate measured as nitrogen, and the term elevated nitrate concentrations refers to those concentrations that exceed $2 \mathrm{mg} / \mathrm{L}$ (as N).

\section{Description of Study Area}

The State of Washington (fig. 1) has a very diverse climate. The north-south trending Cascade Mountains divide the State into a humid western half and a semiarid eastern half. On average, the annual precipitation is about $70 \mathrm{in}$. in western Washington and 20 in. in eastern Washington. Locally, annual precipitation ranges from about 20 to $200 \mathrm{in}$. in western Washington and about 7 to $40 \mathrm{in}$. in eastern Washington.

The surficial geology of Washington also is diverse. Bedrock is exposed in the Cascade and Olympic Mountains in northeastern Washington, and the Columbia River basalt flows cover the southeastern part of the State. Unconsolidated alluvial materials fill in the bottoms of many bedrock valleys and overlie much of Columbia River basalts, and unconsolidated glacial materials cover most of the Puget lowland region.

A map of hydrogeomorphic regions was developed specifically for this study, because a highly detailed map of regional aquifers for Washington was not available (fig. 2). According to Rupert (2003),

“...hydrogeomorphic regions are similar in concept to regional aquifers, but are distinguished from regional aquifers in that hydrogeomorphic regions are delineated on the basis of general geographic locations of geologic materials and not on actual aquifer locations." 


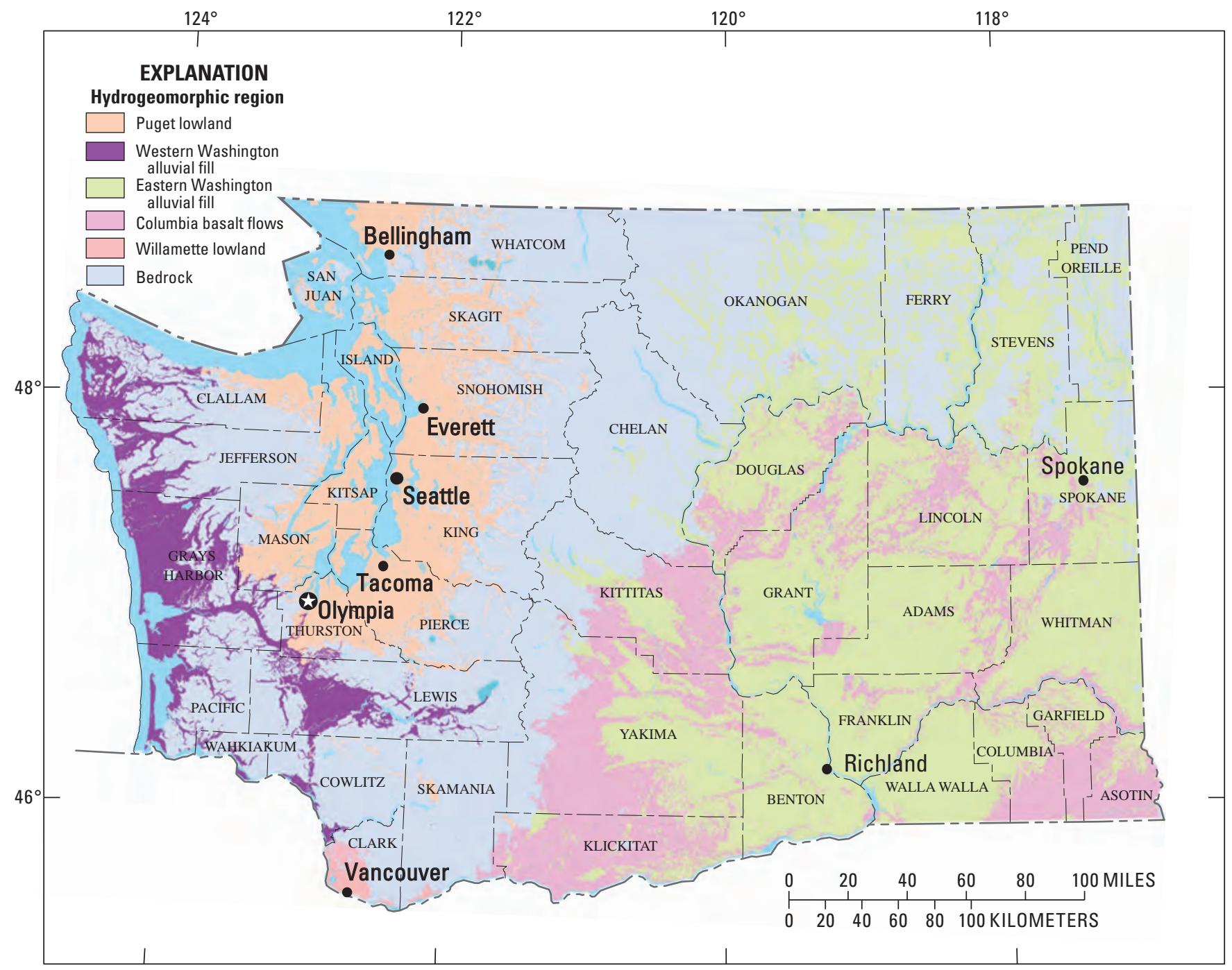

Figure 2. Hydrogeomorphic regions in Washington. 
The hydrogeomorphic regions were delineated based on the surficial geologic map of Washington (Washington Department of Natural Resources, 2005). The hydrogeomorphic regions that were delineated include the glacial material of the Puget lowland, alluvial fill in western and eastern Washington, the Columbia basalt flows, the alluvial material of the Willamette lowland, and the bedrock of northern Washington, the Cascades, and Olympics. In eastern Washington, the alluvial fill hydrogeomorphic region lies on top of the basalt and bedrock units. Therefore, wells in the eastern Washington alluvial fill region were stratified by depth to determine if the wells were deep enough to penetrate the underlying regions. Where possible, well depths were compared to sediment thickness maps (Jones and others, 2006, and Susan Loper, Franklin Conservation District, written commun., 2007) to determine if the wells penetrated the alluvial fill. If such sediment thickness maps were unavailable, wells with depths less than $150 \mathrm{ft}$ were assumed to be in the alluvial fill region. Wells with depths greater than $150 \mathrm{ft}$ were assumed to penetrate into the underlying regions.

Most of the population in Washington resides in the Puget lowland region. Eastern Washington is generally sparsely populated with the exception of a few cities such as Spokane.

\section{Methods of Investigation}

Maps showing the probability of elevated nitrate concentrations in ground water in Washington State were developed in several steps:

1. Relevant anthropogenic, hydrogeologic, and nitrate concentration data were compiled.

2. Nitrate concentrations in ground-water data were overlaid with anthropogenic and hydrogeologic data using a GIS to produce a dataset in which each well with a measured nitrate concentration was attributed with population, land cover, precipitation, recharge, soils, and well depth. These data then were downloaded to a statistical software package for analysis.

3. Several preliminary multivariate models with various combinations of explanatory variables were calibrated.

4. The performance of the multivariate models that best estimated the probability of elevated nitrate concentrations in ground water was evaluated and validated.

5. The multivariate models were entered into the GIS, and the probability maps were constructed.

\section{Description of Logistic Regression}

Logistic regression was selected for this analysis because logistic regression quantifies the relation between a variable of interest (response variable) and one or more variables that affect the variable of interest (explanatory variables). This is conceptually similar to multiple linear regression. However, the response variable in logistic regression is transformed into a binary response (yes or no) variable. This makes logistic regression an excellent tool for modeling aquifer vulnerability to nitrate contamination because logistic regression can quantify the probability that nitrate will exceed a specified concentration. According to Tesoriero and others (1998),

"Logistic regression may identify relations between the occurrence of a constituent and explanatory variables when other methods do not because logistic regression answers a simpler questionwhether a well is expected to have water with a concentration greater than a specified value. In contrast, other methods (e.g., linear regression) try to estimate the absolute concentration of a constituent. Given the many factors related to the source and transport of a constituent in ground water, it is often impossible to predict its concentration; however, it may be possible to predict the probability that the concentration is above a specified level."

In this study, logistic regression models were used to determine the probability of exceedance of $2 \mathrm{mg} / \mathrm{L}$ of nitrite plus nitrate as nitrogen in ground water. For the models, a binary response variable was defined by dividing the measured nitrate concentrations into two groups: those greater than or equal to $2 \mathrm{mg} / \mathrm{L}$ (exceedances) and those less than $2 \mathrm{mg} / \mathrm{L}$ (nonexceedances). The threshold of $2 \mathrm{mg} / \mathrm{L}$ was selected because nitrate concentrations that exceed $2 \mathrm{mg} / \mathrm{L}$ generally are the result of anthropogenic effects (Nolan and others, 1998).

The logistic regression models take the form of

$$
P=\frac{e^{b_{0}+b(X)}}{1+e^{b_{0}+b(X)}},
$$

where

$P$ is the probability of an exceedance,

$e$ is the base of the natural logarithm,

$b_{0}$ is the intercept,

$X$ represents a set of explanatory variables such as land use, soils, or well depth, and

$b$ represents the slope for each of the explanatory variables so that $b(X)=\left[b_{1}\right.$ (land use) $+b_{2}$ (soils) $+b_{3}$ (well depth) $\left.+\ldots . ..\right]$ (Hosmer and Lemeshow, 1989; Helsel and Hirsch, 1992). 
When the probability of an exceedance is plotted versus an explanatory variable, the result is an $S$-shaped curve with the probability being bounded by 0 on the lower end and 1 on the upper end. The SAS statistical software was used to determine (calibrate) values of $b_{0}$ and $b$ that best fit the data using an iteratively reweighted least-squares algorithm (SAS Institute, 1990).

Model performance was evaluated using several statistical measures. Logistic regression calculates several statistical parameters that determine the predictive success of the model. The log-likelihood ratio measures the success of the model as a whole by comparing measured with estimated values (Hosmer and Lemeshow, 1989); specifically, it tests whether model coefficients of the entire model are significantly different from zero. The most significant model is the one with the highest log-likelihood ratio, taking into account the number of explanatory variables (degrees of freedom) used in the model. The log-likelihood ratio can be approximated by a chi-squared distribution, and the computed $p$-value reflects the degree of certainty (significance level) that model coefficients as a whole are different from zero. A $p$-value of 0.05 indicates a significance level of 95 percent, a $p$-value of 0.01 indicates a significance level of 99 percent, and the smallest $p$-value indicates the best model. McFadden's rho-squared (SPSS, Inc., 2000) is a transformation of the log-likelihood statistic and is intended to mimic the $R^{2}$ metric of linear regression. Rhosquared is always between 0 and 1 ; a rho-squared closer to 1 corresponds to a better fit. Rho-squared tends to be smaller than $R^{2}$, so a small number does not necessarily imply a poor fit. Values between 0.2 and 0.4 indicate good results (SPSS, Inc., 2000). The percentage of correct responses is a measure of how many actual nitrate exceedances and nonexceedances are present, compared with what was estimated by the model; the largest number denotes the best model. The percentage of correct responses is calculated as the number of measured exceedances estimated by the model as exceedances, plus the number of measured nonexceedances estimated by the model as nonexceedances, divided by the combined number of measured exceedances and nonexceedances (Nolan and Clark, 1997). Additional information regarding these statistical measures is available in Hosmer and Lemeshow (1989) and Helsel and Hirsch (1992).

The partial-likelihood ratio was used to compare nested models to determine the significance of adding one or more new variables (Helsel and Hirsch, 1992; Nolan and Clark, 1997). A nested model contains all explanatory variables in the original model, plus one or more additional explanatory variables. To determine whether the model is improved by adding the explanatory variable, the logistic regression model is calculated without that new variable. Logistic regression calculates a partial-likelihood ratio. The logistic regression model then is rerun with the additional new explanatory variable; the second model also calculates a partial-likelihood ratio. The difference in partial-likelihood ratios between the two models is calculated and a chi-squared approximation is calculated with degrees of freedom equal to the number of additional variables in the new model. If the $p$-value from the chi-squared distribution is less than 0.05 , the model has been significantly improved at the 95-percent level.

For individual explanatory variables, the $p$-value for the Wald statistic is reported. The Wald statistic can be approximated by a chi-squared distribution and is used to indicate whether individual model coefficients are significantly different from zero. Individual coefficients were considered to be statistically significant if the $p$-value of the Wald statistic was less than or equal to 0.05 . The $p$-value for the Wald statistic can be considered similar to the $p$-value for the slope of a line in linear regression. In linear regression, the slope of the line is considered to be statistically different from a horizontal line (with a slope of zero) if the $p$-value is less than 0.05. Similarly, the regression coefficients are considered to be statistically different from zero if the $p$-values are less than 0.05 .

Multicollinearilty is the result of strong correlation between explanatory variables, and is a major concern for multivariate logistic regression models. Multicollinearity may result in incorrect signs and magnitudes of regression coefficients, thereby, leading to incorrect conclusions about relations between explanatory and response variables. Pearson correlation coefficients and multicollinearity diagnostic statistics were examined to assess the multicollinearity in the models. A strong correlation between two variables was indicated if the correlation coefficient was greater than 0.7. However, Pearson correlation coefficients would not detect cases where multiple explanatory variables may be interdependent. In these cases, the Tolerance and Variance Inflation Factor (VIF) can be used to detect multicollinearity. According to Gurdak and Qi (2006), the Tolerance and VIF are based on linear regression analysis of explanatory variables. The Tolerance is defined as $1-R^{2}$, where $R^{2}$ is the coefficient of determination for the regression of one independent variable on all remaining independent variables (Allison, 1991; Menard, 2002). The VIF is equal to the reciprocal of the tolerance and describes how inflated the variance of coefficient is compared to what it would be if there were no multicollinearity (Allison, 1991). Although no formal thresholds exist to use for the Tolerance or VIF in detecting the presence of multicollinearity, Allison (1991) suggests that Tolerance values less than 0.4 (VIF greater than 2.5) may indicate the presence of multicollinearity. 


\section{Compilation of Nitrate Concentration Data into a Response Variable}

The binary response variable of nitrate concentrations exceeding or not exceeding a selected concentration (exceedances and nonexceedances, respectively) was computed from the WDOH public-water supply system database. The WDOH dataset contained more than 60,000 nitrate analyses from samples collected between April 1979 and September 2006. Because nitrate concentrations and landuse characteristics would be expected to have changed over such a long period, the dataset was reduced to include only the samples collected after January 1, 1995. Reporting level limits in this smaller dataset ranged from less than 0.001 to less than $7 \mathrm{mg} / \mathrm{L}$. Because the wide range of reporting levels would adversely affect the computation of the response variable, analyses with reporting levels greater than $0.5 \mathrm{mg} / \mathrm{L}$ were omitted, which resulted in the exclusion of about 850 samples.

Once the dataset of nitrate analyses was finalized, a single nitrate concentration was calculated for each water source, as many of the sources had multiple samples. This was accomplished by computing the median value of all samples for each water source. The resulting dataset then was further reduced to exclude all water sources that were not from an individual well, had no location information, or had location information of questionable quality. The final dataset contained median nitrate concentrations for about 12,600 wells.

The final dataset contains far fewer wells in eastern Washington than in western Washington, but nitrate concentrations were elevated in a larger percentage of wells in eastern Washington (fig. 3). Nitrate concentrations were higher in wells in the Columbia basalt flow and the eastern Washington unconsolidated hydrogeomorphic regions than the other regions of the State (fig. 4). The regional median nitrate concentrations ranged from $1.4 \mathrm{mg} / \mathrm{L}$ in the eastern Washington alluvial fill region to the reporting limit of 0.5 $\mathrm{mg} / \mathrm{L}$ in the western Washington alluvial fill, bedrock, and Puget lowland regions.

Nitrate concentrations in ground water from wells in the USGS and Washington State Department of Ecology databases (fig. 5) were used as the model validation dataset (1,813 wells). Only data collected after 1995 were used, and all known public-supply well samples were excluded so no data were duplicated in the calibration dataset. As with the calibration dataset, nitrate concentrations in the validation dataset were elevated in a larger percentage of wells in eastern Washington.

\section{Compilation of Anthropogenic and Hydrogeologic Data into Explanatory Variables}

Explanatory variables that were compiled and evaluated included well depth (depth to bottom of well from land surface), ground-water recharge rate, average annual precipitation, population density, land use, nitrogen application amounts, soil available water capacity, soil hydrologic group, soil drainage group, soil permeability, soil clay content, amount of organic matter in soil, and hydrogeomorphic region (table 1). Data for explanatory variables were obtained from several sources.

Well depth was obtained for each wells, if available, from the WDOH well database. Ground-water recharge rates were taken from Wolock (2003) and average annual precipitation was from Spatial Climate Analysis Service-Oregon State University (2006). Population density was retrieved from the U.S. Bureau of the Census for the 2000 (GeoLytics, 2001) census year. Land-use data were compiled from the 1992 National Land Cover Dataset (Vogelmann and others, 2001), which was enhanced with GIRAS land use/land cover data modified as described in Price and others (2003) to more accurately represent alpine tundra, orchards, vineyards, and residential areas. Areas were classified as urban, agricultural, or other (which includes forest, rangeland, wetlands, and barren areas). All soil criteria (available water capacity, hydrologic group, drainage group, clay content, permeability rate, and organic matter content) were obtained from Schwarz and Alexander (1995), which utilizes the STATSGO soil database (U.S. Department of Agriculture, 1993). The soil data include weighted vertical averaging of many of the soil characteristics contained in the database.

Estimates of agricultural and urban nitrogen fertilizer application amounts were computed as the product of the rate of nitrogen fertilizer application (in kilograms per square kilometer per year) and the total applicable land use area within a specified radius of each well. Nitrogen application rates were determined by allocating the farm and nonfarm county-level nitrogen application amounts of Ruddy and others (2006) to the compiled land-use data. For each county, the approximate average nitrogen mass from 1995 to 2004 was divided by the total area of allocated land cover to determine the nitrogen application rate.

The percentage of each land-use type and the amount of nitrogen fertilizer applied within a specified radius (buffer) of each well were calculated and then related to nitrate concentrations. The optimal radius to use for the land-use and fertilizer application data was determined by performing logistic regression analyses at different radii around the wells. 




Figure 3. Nitrate concentrations in water from wells in Washington from the Washington State Department of Health database (1995-2006). 


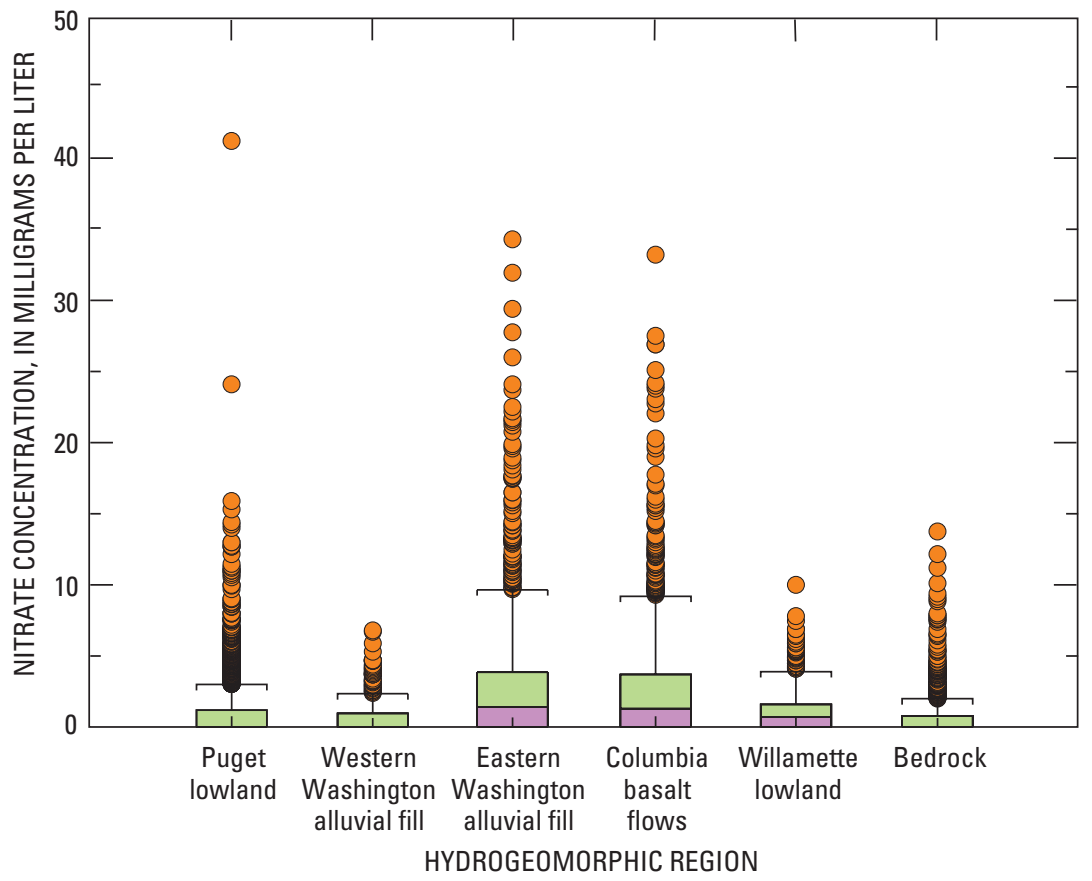

\section{EXPLANATION}

- Outlier

$\neg 1.5$ times interquartile range

$75^{\text {th }}$ percentile

Median

$25^{\text {th }}$ percentile

Figure 4. Nitrate concentrations in ground-water samples collected in hydrogeomorphic regions in Washington from the Washington State Department of Health database (1995-2006).

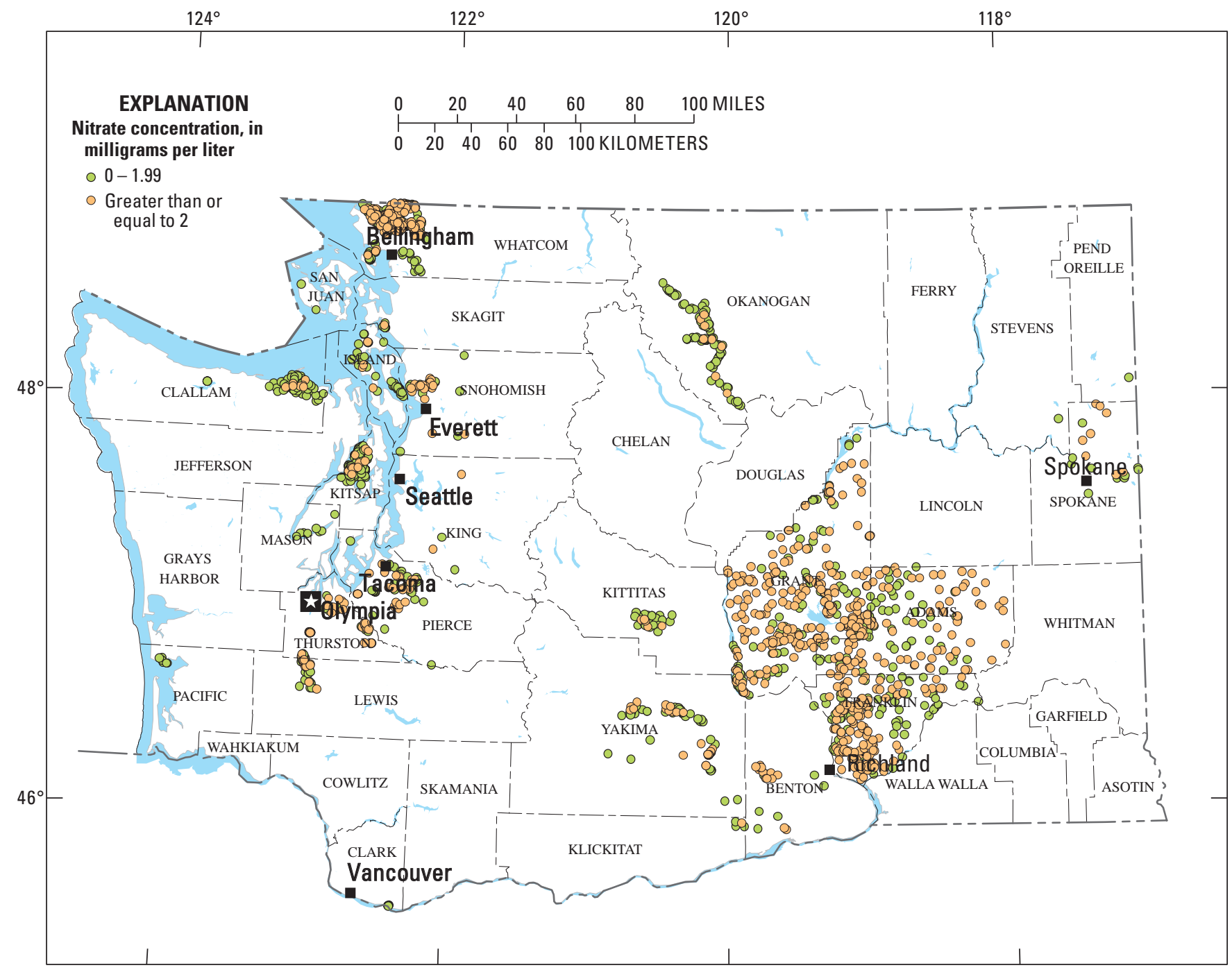

Figure 5. Nitrate concentrations in water from wells in Washington from the U.S. Geological Survey and Washington State Department of Ecology databases (1995-2006). 
Table 1. Summary of anthropogenic and natural explanatory variables used for model development.

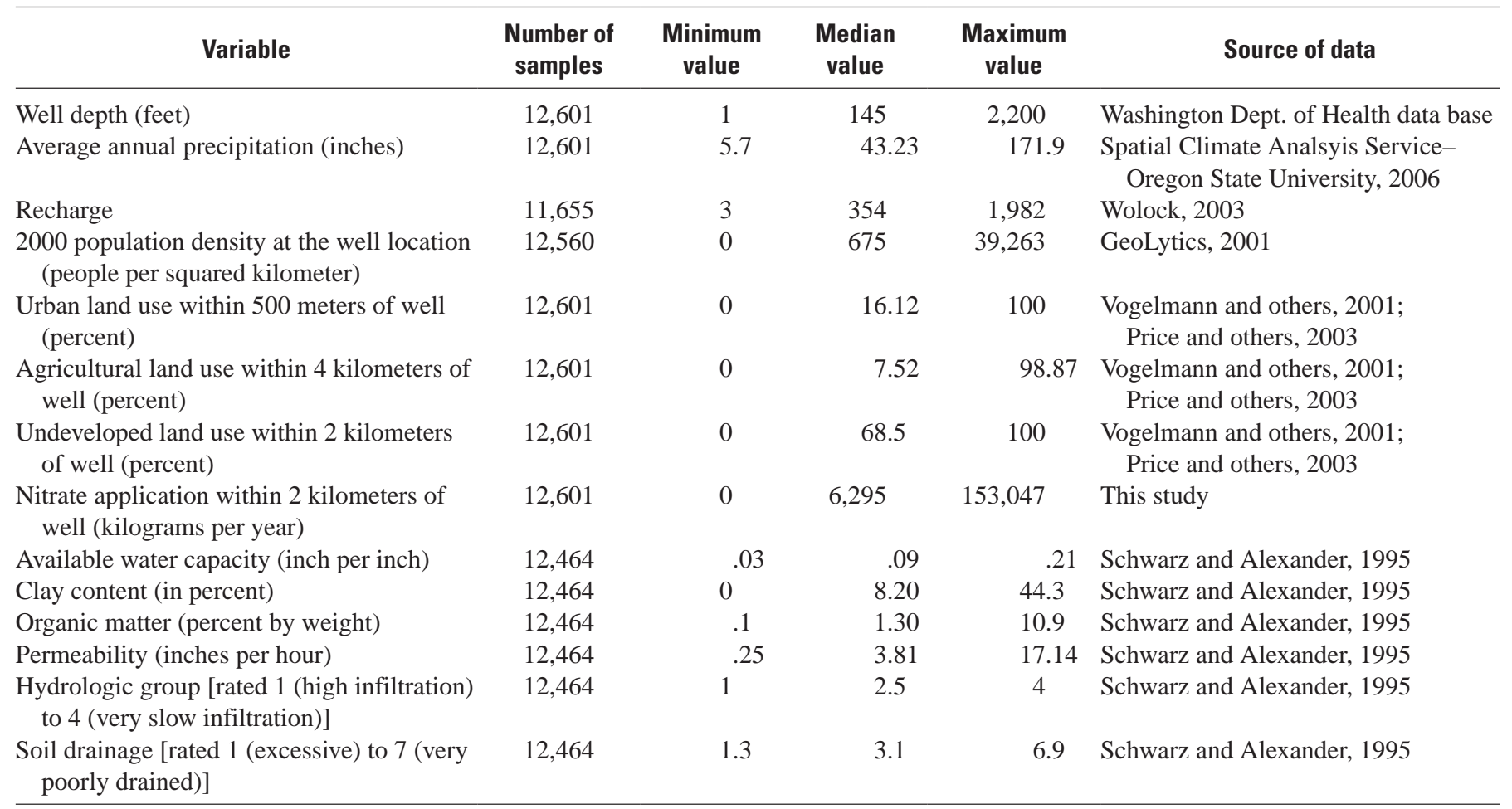

McFadden's rho-squared was calculated for each buffer size to determine the most significant relation (fig. 6). The optimum buffer sizes were $4,000 \mathrm{~m}$ for agricultural lands, 2,000 $\mathrm{m}$ for undeveloped lands, $500 \mathrm{~m}$ for urban lands, and 2,000 $\mathrm{m}$ for nitrate application amounts.

Percentage of land cover, nitrate application amounts, recharge, precipitation, population density, soils, and well depth were modeled as continuous variables. Because of their categorical nature, hydrogeomorphic regions were modeled as discrete variables. Discrete variables were coded as " 1 "

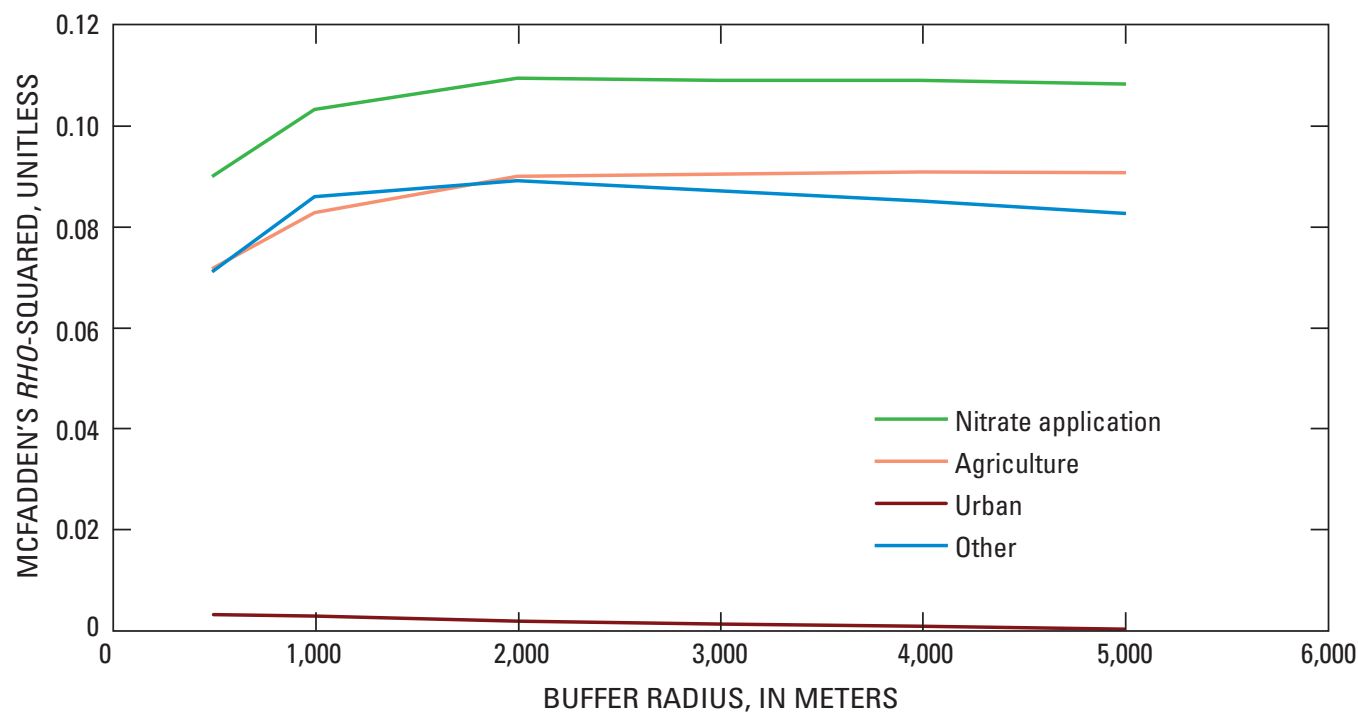

Figure 6. McFadden's rho squared from relations of amount of nitrogen application and percentage of agricultural, urban, and undeveloped lands within circular buffers around wells with nitrate concentrations greater than 2 milligrams per liter in ground water in Washington.

if a well was located in a particular region and coded " 0 " if the well was not located in that region. For example, if a well was located in the western Washington alluvial fill region, then those wells in that region would be coded 1 and all other wells would be coded 0. Hosmer and Lemeshow (1989) further describe the use of continuous and discrete variables in logistic regression. Reference cell coding was used with the Puget lowland region as the reference variable. 


\section{Logistic Regression Results}

Based on the relations between the explanatory variables and the measured elevated nitrate concentrations, various logistic regression models were developed to estimate the probability that ground water will exceed a nitrate concentration of $2 \mathrm{mg} / \mathrm{L}$. All possible combinations of the explanatory variables were evaluated to develop the models. The performance of these models was evaluated using the log-likelihood ratio, McFadden's rho-squared, the $p$-values for each variable included in the models, and the percentage of correct responses.

The two best performing models-one with and one without hydrogeomorphic regions - for estimating the probability of nitrate concentrations exceeding $2 \mathrm{mg} / \mathrm{L}$ were identified. Models with and without hydrogeomorphic regions were developed because of the possibility that different relations between explanatory and response variables may occur in each of the hydrogeomorphic regions. This allowed a comparison between the model that included the hydrogeomorphic regions with the one that did not to determine if inclusion of the hydrogeomorphic regions significantly improved model performance.

Well depth, average annual precipitation, percentage of agricultural land within a 4-km buffer around the well, population density, and soil drainage were the significant explanatory variables in both of the best performing models (table 2). Overall performance of both models was good, with the chi-squared $p$-value calculated from the $\log$-likelihood ratio of the entire model less than 0.001 , McFadden's rhosquared of about 0.19 , and the percentage of correct responses greater than 81 percent (table 3). The two models performed equally well, with identical percentages of correct responses.

Table 2. Regression coefficients and individual $p$-values of independent variables for the two logistic regression models with and without hydrogeomorphic regions that were significantly related with nitrate concentrations greater than 2 milligrams per liter in ground water in Washington.

\begin{tabular}{|c|c|c|c|c|}
\hline \multirow[b]{2}{*}{ Independent variable } & \multicolumn{2}{|c|}{ With hydrogeomorphic region } & \multicolumn{2}{|c|}{ Without hydrogeomorphic region } \\
\hline & $\begin{array}{l}\text { Regression } \\
\text { coefficients }\end{array}$ & $p$-values & $\begin{array}{l}\text { Regression } \\
\text { coefficients }\end{array}$ & $p$-values \\
\hline Logistic regression constant & 1.6132 & $<0.0001$ & 1.3857 & $<0.0001$ \\
\hline Well depth, in feet & -.00436 & $<.0001$ & -.00388 & $<.0001$ \\
\hline Average annual precipitation, in inches & -.0252 & $<.0001$ & -.026 & $<.0001$ \\
\hline $\begin{array}{l}\text { Percentage of agricultural land within a } \\
\text { 4-kilometer buffer }\end{array}$ & .0276 & $<.0001$ & .0275 & $<.0001$ \\
\hline 2000 population density & .000064 & $<.0001$ & .00007 & $<.0001$ \\
\hline Soil drainage & -.5796 & $<.0001$ & -.5554 & $<.0001$ \\
\hline \multicolumn{5}{|l|}{ Hydrogeomorphic region } \\
\hline Eastern Washington basin fill & -.3349 & .0011 & - & - \\
\hline Columbia basalts & .1583 & .128 & - & - \\
\hline Bedrock & -.4621 & $<.0001$ & - & - \\
\hline Willamette basin & .0337 & .7963 & - & - \\
\hline Western Washington basin fill & -.7302 & $<.0001$ & - & - \\
\hline
\end{tabular}

Table 3. Statistical results from models that estimate the probability of nitrate concentrations exceeding 2 milligrams per liter in ground water in Washington.

[Abbreviation: <, less than.]

\begin{tabular}{lcc}
\hline \multicolumn{1}{c}{ Statistical results } & \multicolumn{2}{c}{ Model } \\
\cline { 2 - 3 } & $\begin{array}{c}\text { With } \\
\text { hydrogeomorphic } \\
\text { region }\end{array}$ & $\begin{array}{c}\text { Without } \\
\text { hydrogeomorphic } \\
\text { region }\end{array}$ \\
\hline Log-likelihood ratio & 2,452 & 2,378 \\
$p$-value & $<.0001$ & $<.0001$ \\
McFadden's rho-squared & .193 & .187 \\
Percentage of correct responses & 81.33 & 81.33 \\
\hline
\end{tabular}


The positive and negative signs of the model coefficients were as expected. Well depth showed a negative correlation with elevated nitrate concentrations as nitrate concentrations usually decrease with depth below land surface. The relation between percentage of agricultural land use near a well and elevated nitrate concentrations was positive. This indicates that agricultural fertilizer is a large source of nitrate to ground water. The relation between population density and elevated nitrate concentrations also was positive, which is likely the result of residential fertilizer usage and septic system inputs. The relation between elevated nitrate concentrations and soil drainage was negative indicating that the probability of elevated nitrate concentrations increases beneath soils that are well drained. Soils that are poorly drained may have an increased likelihood of fostering denitrifying conditions, thereby decreasing the amount of nitrate available to leach into the ground water. The relation between elevated nitrate concentrations and precipitation also was negative, which is likely due to the larger percentage of elevated nitrate concentrations in eastern Washington, which receives less precipitation than western Washington.
Alternative measures of model performance were generated regressing the measured and estimated probabilities of elevated nitrate concentrations from wells included in the calibration dataset (fig. 7). Nitrate concentrations from the calibration wells were converted to a binary classification of 0 for nitrate concentrations less than $2 \mathrm{mg} / \mathrm{L}$ and 1 for those greater than $2 \mathrm{mg} / \mathrm{L}$. This binary conversion allowed the percentage of actual detections to be calculated and compared to the estimated probabilities for each 10 percent decile. The estimated and measured number of exceedances and nonexceedances were similar for both models with and without hydrogeomorphic regions, as indicated by $R^{2}$ values of 0.9748 and 0.9792 , respectively, with no systemic bias as shown by the 1:1 line in figure 7. Pearson's correlation coefficients and Tolerance and VIF statistics detected no multicollinearity for the explanatory variables included in the models. Pearson's correlation coefficients were all less than 0.5 , tolerance was greater than 0.67 , and VIF less than 1.5 .

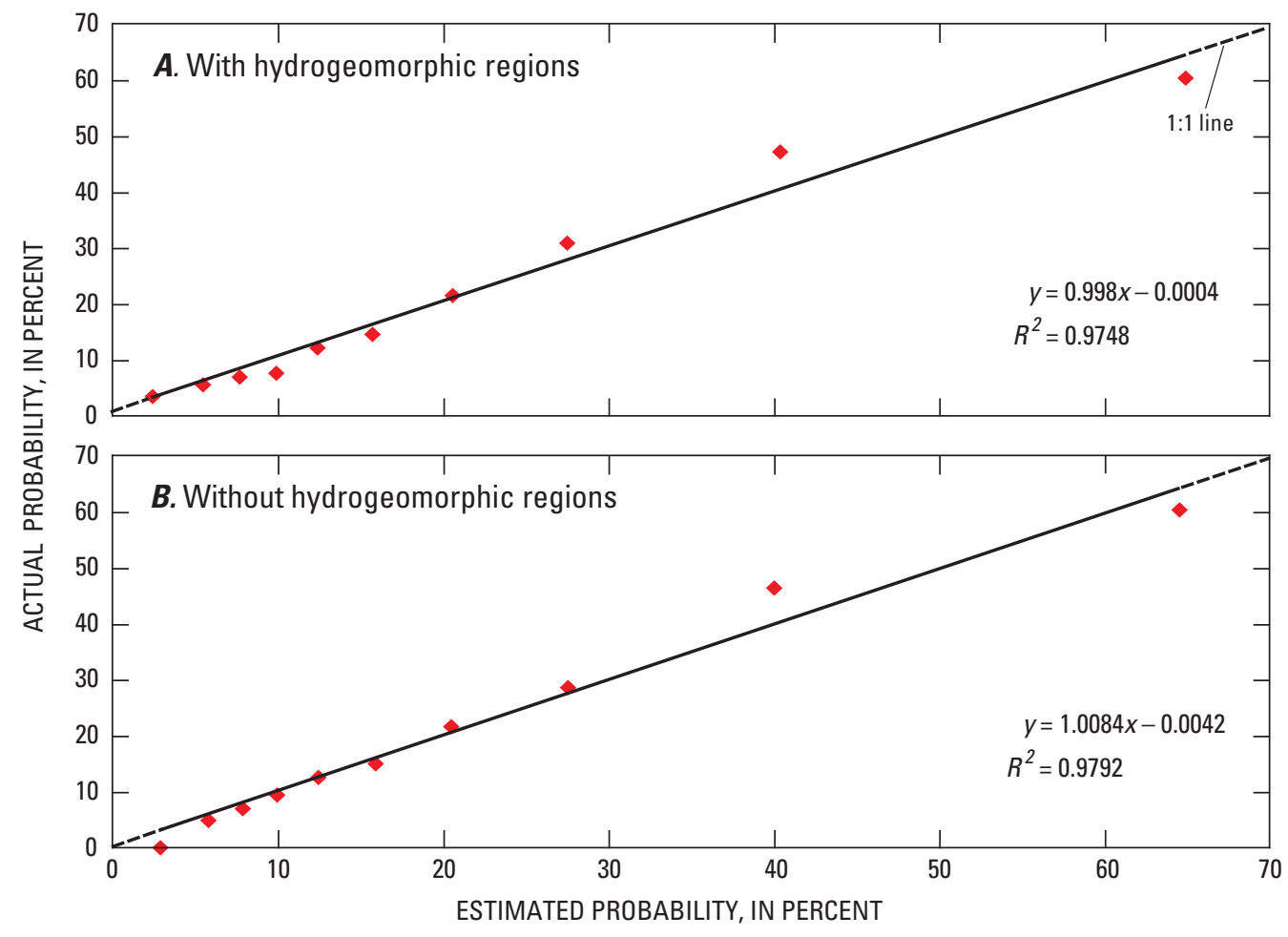

Figure 7. Percentage of actual nitrate concentrations greater than 2 milligrams per liter $(\mathrm{mg} / \mathrm{L})$ and the estimated probability of nitrate concentrations greater than $2 \mathrm{mg} / \mathrm{L}$ in the calibration dataset. 


\section{Validation of Nitrate Models}

To validate the models, the estimated probabilities of elevated nitrate concentrations for wells in the validation dataset from USGS and Department of Ecology were computed and compared to the actual probabilities (fig. 8). Nitrate concentrations from the validation wells were converted to a binary classification of 0 for nitrate concentrations less than $2 \mathrm{mg} / \mathrm{L}$ and 1 for concentrations greater than $2 \mathrm{mg} / \mathrm{L}$. This binary conversion allowed the percentage of measured detections to be calculated and compared to the estimated probabilities for each 10 percent decile. The relation between the actual percentage of wells with a nitrate concentration greater than $2 \mathrm{mg} / \mathrm{L}$ and the estimated probabilities had an $R^{2}$ of 0.9061 for the model without hydrogeomorphic regions and 0.9173 for the model with hydrogeomorphic regions. The validation of the model that included hydrogeomorphic regions was not as strong because some regions had few data points. Overall, both logistic regression models tended to underestimate the actual probability for the validation dataset by about 10 percent.

\section{Estimating the Probability of Elevated Nitrate Concentrations in Ground Water}

Maps showing the probability of detecting elevated nitrate concentrations in ground water throughout Washington State were generated using the logistic regression models and a GIS (figs. 9-10). To generate the maps, a $500 \times 500$-meter grid was constructed that covered the entire State. A well was assumed to be in the center of each grid cell and the nitrate concentration in each well was assumed to represent the nitrate concentrations in ground water for the entire grid cell. For the model without hydrogeomorphic regions (fig. 9A), the amount of agricultural land use within a 4-km radius from the center of each cell was calculated; the annual average precipitation, population density, and soil drainage class were determined; a well depth of interest was selected; and probabilities of nitrate concentration exceedances were determined using equation (1) and the coefficients in table 2 . The probabilities were then mapped using a GIS. The process for the model with hydrogeomorphic regions (fig. $9 B$ ) was similar, but included the hydrogeomorphic region of each cell.
Estimated probabilities of nitrate concentrations exceeding $2 \mathrm{mg} / \mathrm{L}$ in wells drilled to $145 \mathrm{ft}$ below land surface (the median well depth for the calibration dataset) range from 0 to greater than 95 percent for both models with and without hydrogeomorphic regions (fig. 9). The high probabilities of elevated nitrate concentrations are most widespread in areas of eastern Washington that have a high density of agricultural land use. The high probabilities of elevated nitrate concentrations beneath the urban and agricultural areas in the Puget lowland are less widespread than in the agricultural areas of eastern Washington, but probabilities do exceed 50 percent in selected areas (fig. 10). Conversely, regions of the State with little agriculture or urban land use have less probability of exceeding a nitrate concentration of $2 \mathrm{mg} / \mathrm{L}$. These types of maps can be generated for any depth of interest, with probabilities of elevated nitrate concentrations decreasing with increasing well depth. 


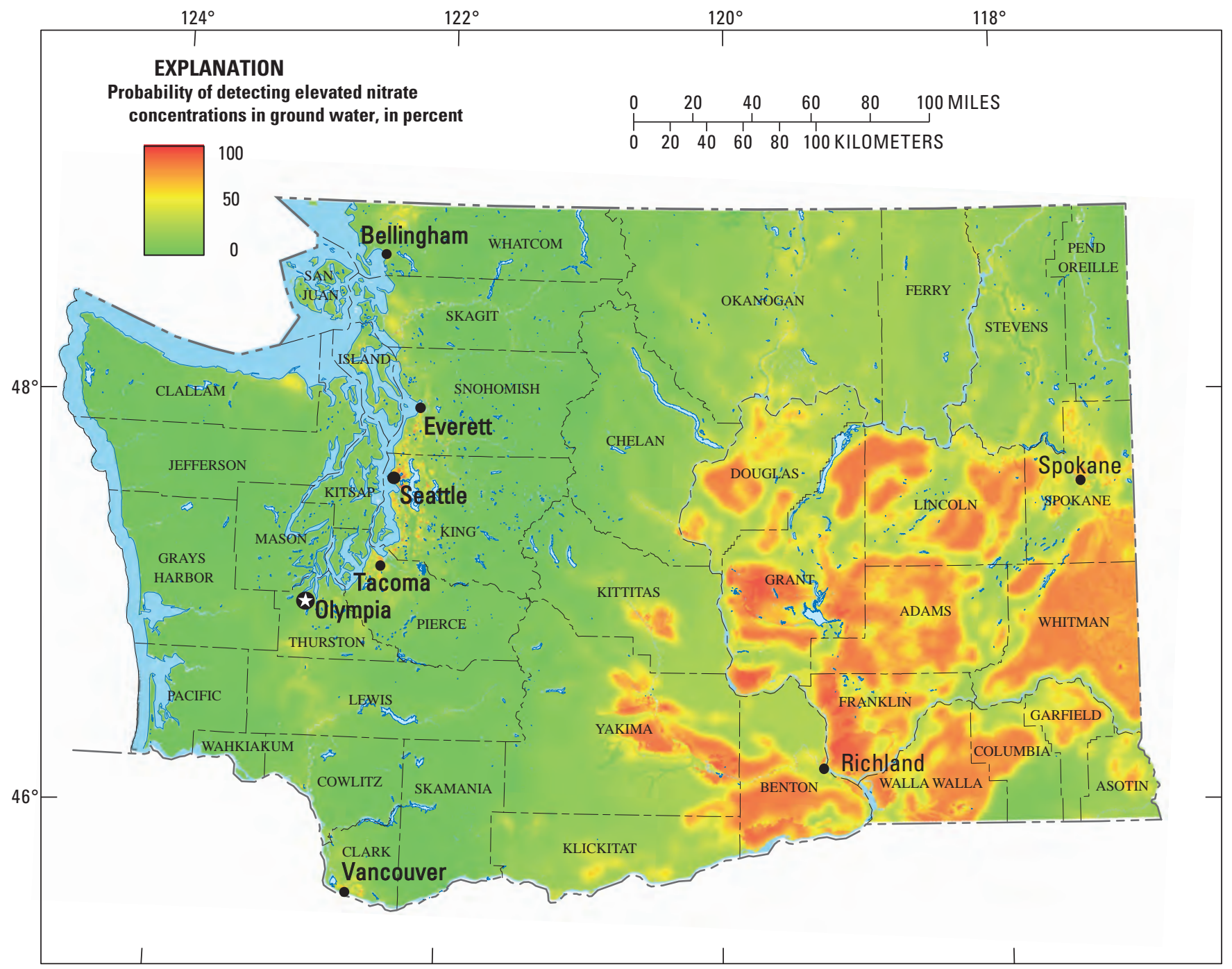

A. Without hydrogeomorphic regions.

Figure 9. Probability of detecting nitrate concentrations greater than 2 milligrams per liter in ground water at a depth of 145 feet below land surface for the two logistic regression models with and without hydrogeomorphic regions, Washington. 


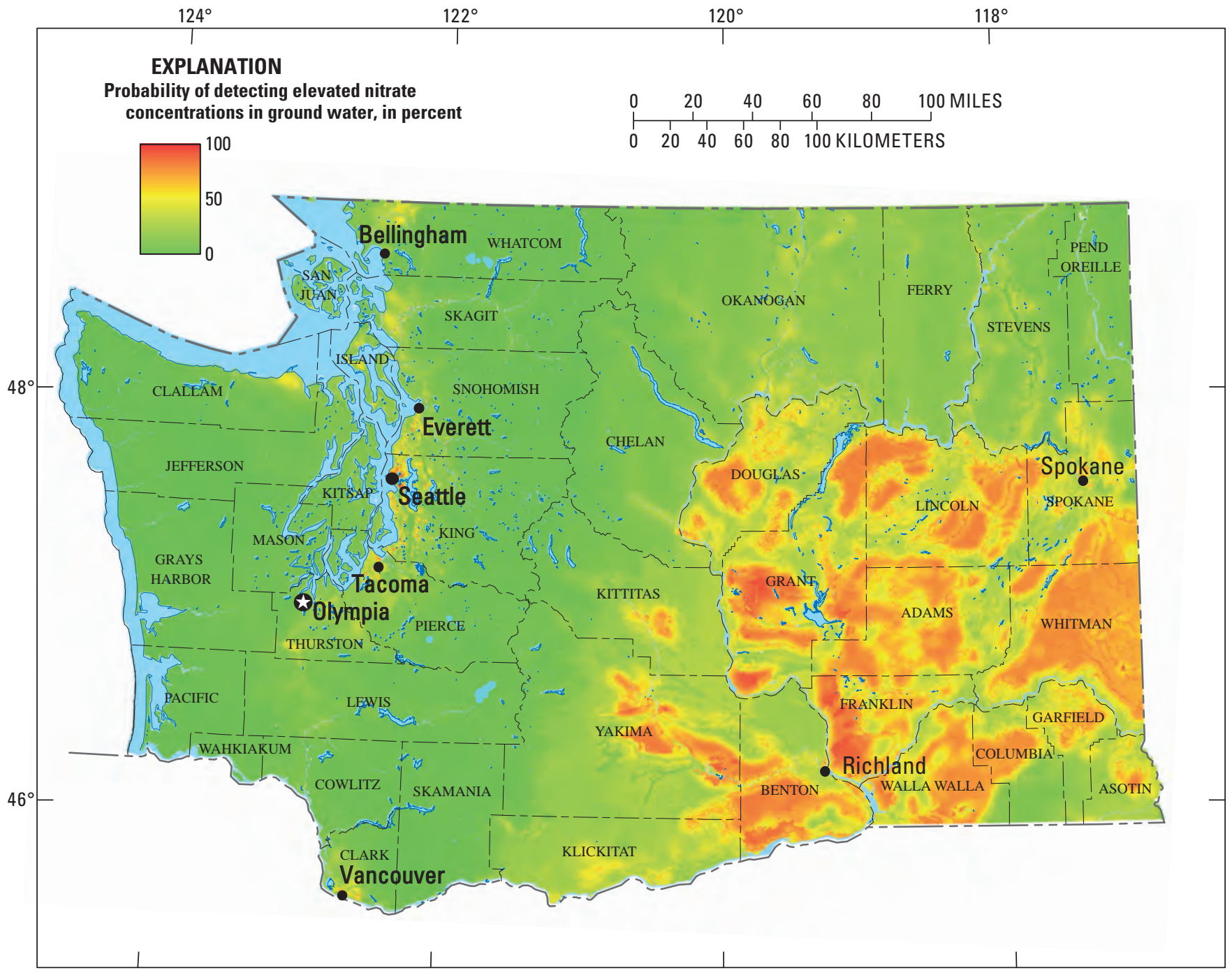

B. With hydrogeomorphic regions.

Figure 9.-Continued. 


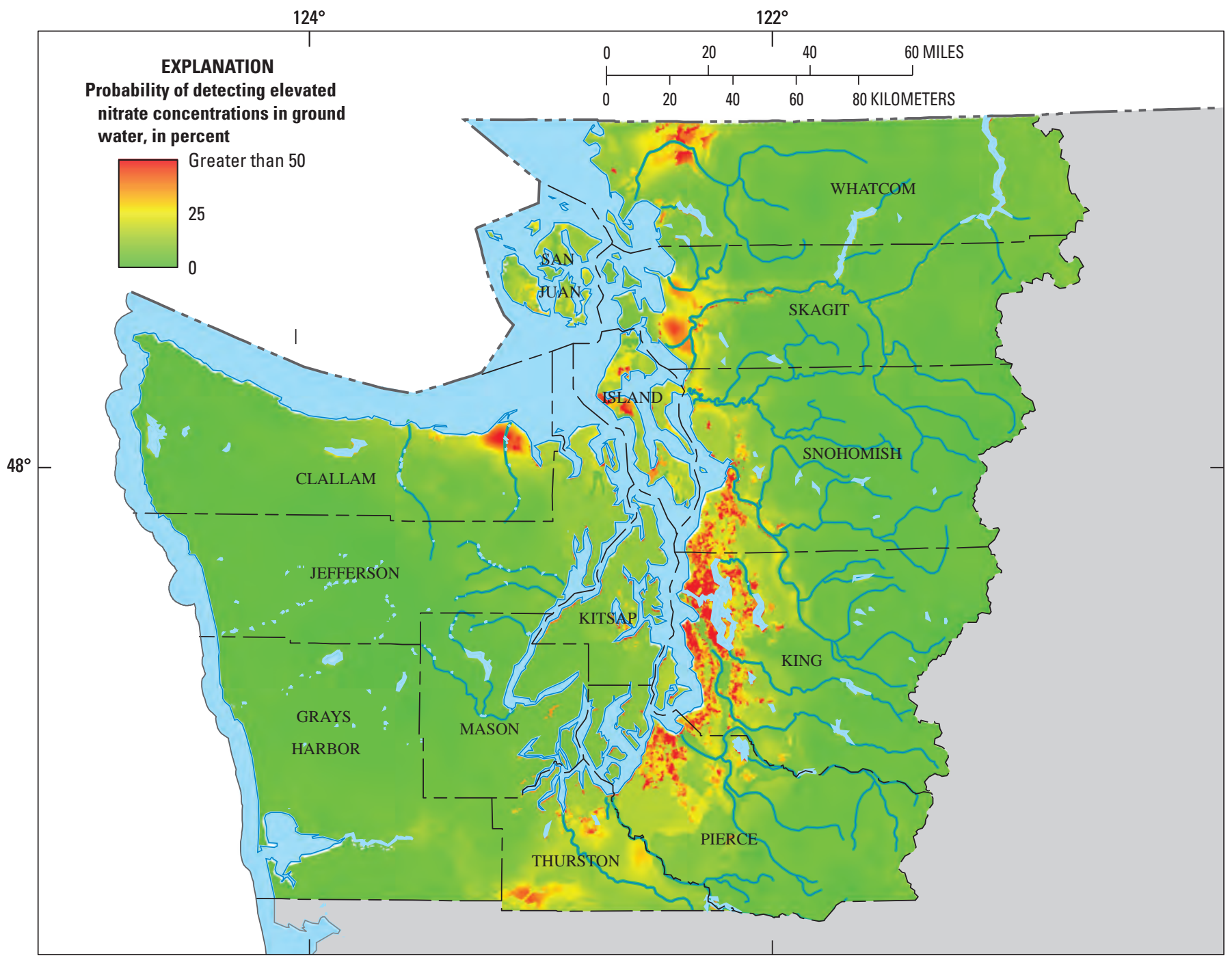

A. Without hydrogeomorphic regions.

Figure 10. Probability of detecting nitrate concentrations greater than 2 milligrams per liter in ground water at a depth of 145 feet below land surface for the two logistic regression models with and without hydrogeomorphic regions, Puget Sound region, Washington. 


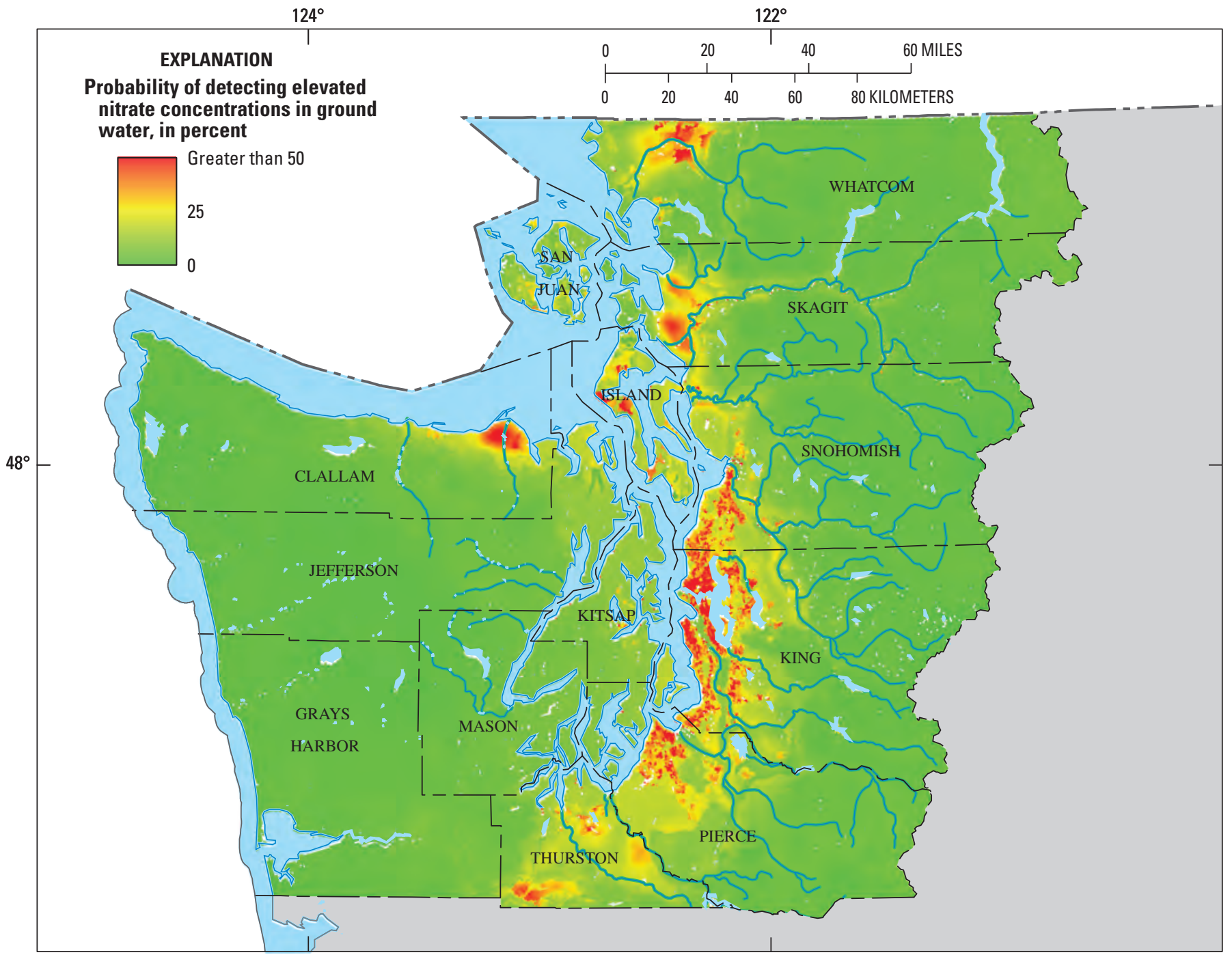

B. With hydrogeomorphic regions.

Figure 10.-Continued. 
In addition to maps displaying the probability of elevated nitrate concentrations, the logistic regression models can be used to generate maps showing the depth to which wells need to be drilled to have a specific probability of obtaining water with a nitrate concentration less than $2 \mathrm{mg} / \mathrm{L}$. This can be done by selecting the probability of a specific elevated nitrate concentration, using the coefficients in table 2 , and solving equation (1) for the well depth. For example, by fixing the probability of exceeding nitrate concentrations of $2 \mathrm{mg} / \mathrm{L}$ at 10 percent, wells would need to be drilled to a depth of more than $1,000 \mathrm{ft}$ in some regions in order to have a 90-percent probability of obtaining ground water with nitrate concentrations less than $2 \mathrm{mg} / \mathrm{L}$ (fig. 11A). In general, wells installed in the agricultural areas of eastern Washington need to be drilled to a depth of at least 750 to $1,500 \mathrm{ft}$ to have a 90-percent probability of obtaining water with nitrate concentrations less than $2 \mathrm{mg} / \mathrm{L}$. Likewise, wells in the urban and agricultural areas of the Puget lowlands would need to

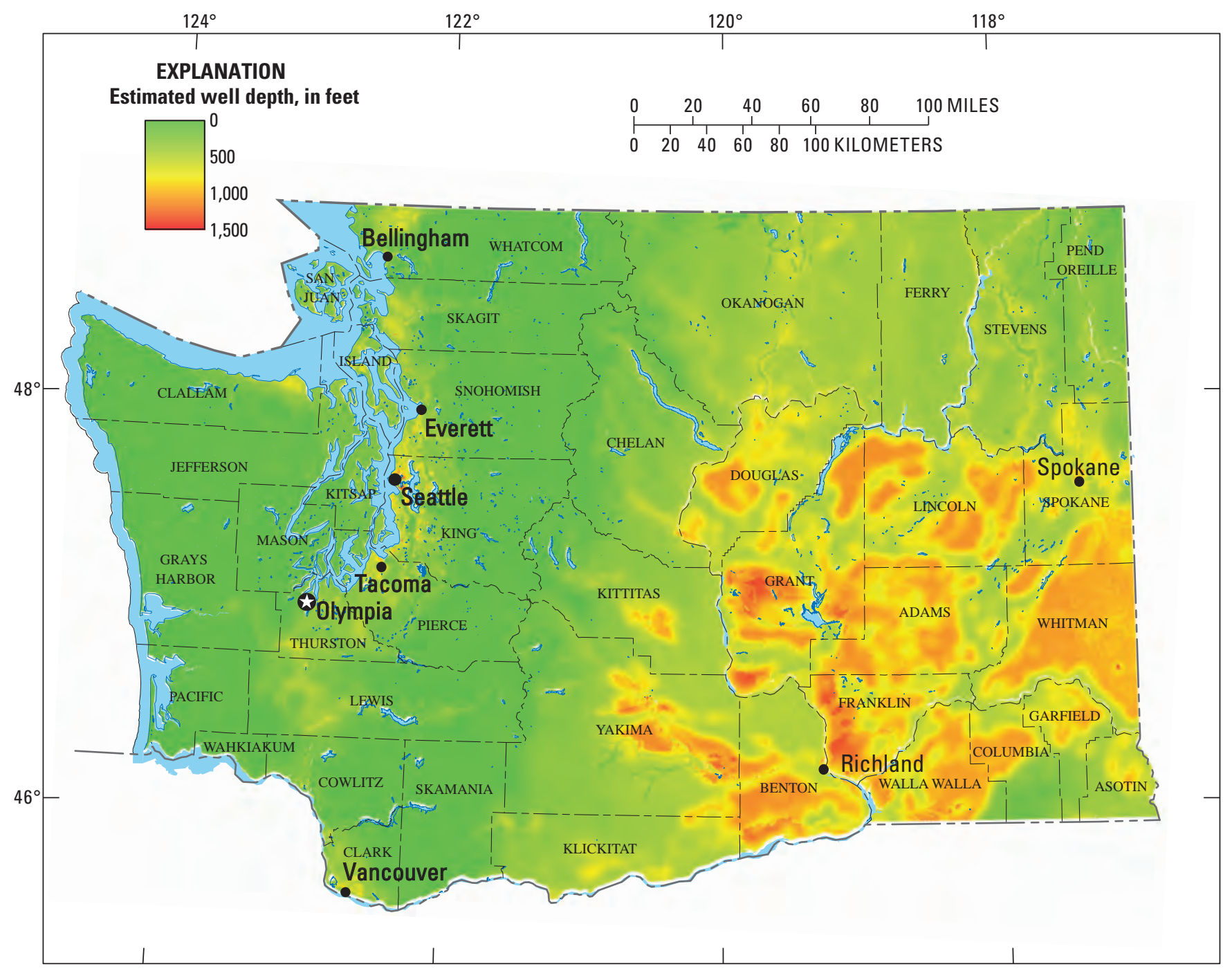

A. Without hydrogeomorphic regions-State of Washington.

Figure 11. Depth to which wells need to be drilled for at least a 90-percent probability of detecting a nitrate concentration less than 2 milligrams per liter in ground water for the logistic regression model without hydrogeomorphic regions, State of Washington and Puget lowlands. 
be drilled to a depth of at least $400 \mathrm{ft}$ (fig. $11 B$ ). Of course in some areas, it may not be possible to obtain drinkable water from a well drilled that deep so the probability of obtaining water with nitrate concentrations less than $2 \mathrm{mg} / \mathrm{L}$ would be less in a shallower well. Additionally, the inclusion of wells that are open to multiple hydrogeologic units could bias the estimated depths. In these cases, ground water with high nitrate concentrations enter the well from open intervals located at shallower depths. For example, many wells on the Columbia Plateau have wells that are only cased to the top of the basalts with very long uncased sections continuing down through the basalts. These shallow casings allow shallow ground water to enter the deeper wells. Casing depth has been shown to be preferable explanatory variable in these situations (Frans, 2000); however, casing depths were not available as part of the WDOH database.

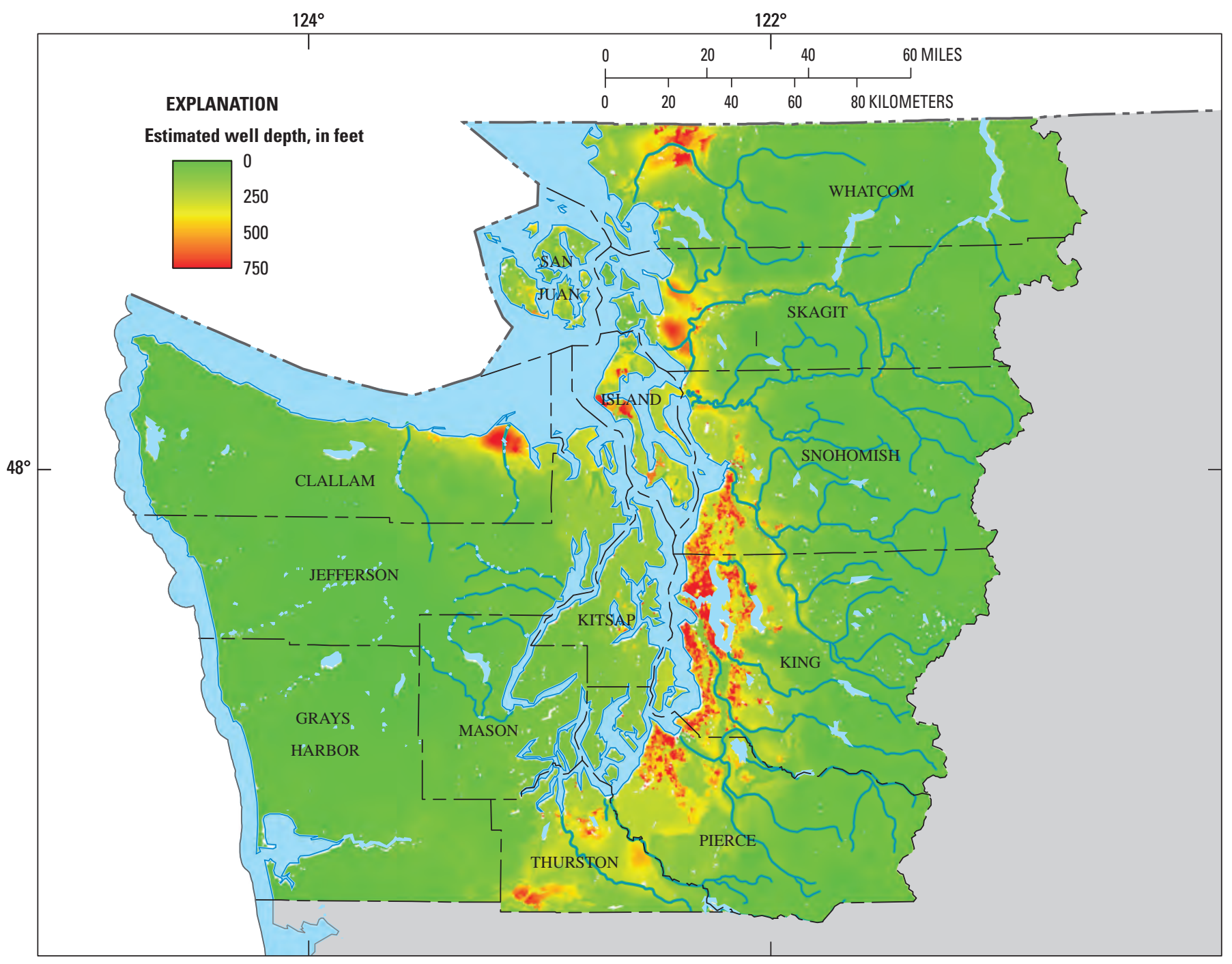

\section{B. Without hydrogeomorphic regions-Puget lowlands.}

Figure 11.-Continued. 


\section{Appropriate Uses of the Probability Maps}

The probability maps developed for this study illustrate the estimated probability of nitrate concentrations exceeding $2 \mathrm{mg} / \mathrm{L}$ in ground water in Washington. The probability maps do not show actual nitrate contamination of ground water. In addition, inherent uncertainty is associated with these maps. Uncertainty in the estimates is the result of data errors in the well database and GIS-based explanatory variables and estimated error in developing the logistic regression coefficients. Higher resolution data, particularly for the soils and nitrate application data, would improve the models.

The maps in this report are intended for regional scale use only and have limitations for use at the field-scale. The maps are not appropriate at any scale larger than 1:250,000, as determined by the STATSGO soil data, which has the smallest scale of the explanatory variables used in the models. Many unaccounted for field-scale complexities affect the concentration of nitrate in ground water and in a given well. For example, the models do not account for point sources of nitrate or preferential pathways in the soil. Although a well may be installed in a region with an estimated high probability of elevated nitrate concentration, the well may in fact actually yield water with low nitrate concentrations due to complexities that cannot be represented in regional-scale models such as those developed in this study.

In addition to the significant explanatory variables of agricultural land use amounts, population density, precipitation, well depth, and soil drainage group, other variables also can have an important effect on nitrate concentrations. The absence of an explanatory variable from the model does not mean that the variable does not have an important effect on nitrate concentrations. In many cases, if two or more explanatory variables are closely correlated with each other, only one of the variables will be incorporated into the model to account for the effects of both variables. For example, soil drainage class and soil hydrologic group are well correlated, therefore, only one of the variables was included.

\section{Summary}

Logistic regression was used to relate anthropogenic and natural factors to the occurrence of elevated nitrate concentrations in the State of Washington and develop models that estimate the probability of nitrate concentrations in ground water exceeding 2 milligrams per liter. Explanatory variables that were considered for inclusion in the models included hydrogeomorphic regions, soil characteristics, ground-water recharge rates, precipitation, land use, well depth, population density, and the amount of fertilizer applied annually near the well.

Two models that best estimate the probability of elevated nitrate concentrations were selected: one with and one without hydrogeomorphic regions. Other variables that were included in these models were well depth, percentage of agricultural land use within 4 kilometers of a well, average annual precipitation, population density, and soil drainage class. Relations between the estimated probability of detecting elevated nitrate and the actual percentage of wells with elevated nitrate concentrations were good for both models with $R^{2}$ values greater than 0.9 .

Maps showing the estimated probability of detecting elevated nitrate concentrations indicate that the agricultural regions are most at risk followed by urban regions. Areas of the State that are not affected by agricultural or urban areas had much lower probabilities of detecting elevated nitrate concentrations. Maps also were generated that show the estimated depths to which wells would need to be drilled in order to have a 90-percent probability of obtaining water with nitrate concentrations less than 2 milligrams per liter. These depths frequently exceed 1,000 feet in the agricultural regions, although wells in urban areas generally would need to be drilled to depths in excess of 400 feet.

\section{References Cited}

\author{
Allison, P.D., 1991, Logistic regression using the SAS \\ system-Theory and application: Cary, N.C., SAS Institute \\ Inc., $288 \mathrm{p}$. \\ Centers for Disease Control and Prevention, 1996, \\ Spontaneous abortions possibly related to ingestion of \\ nitrate-contaminated well water, La Grange County, \\ Indiana, 1991-1994: Morbidity and Mortality Weekly \\ Report, v. 45, p. 569-572.
}

Ebbert, J.C., Embrey, S.S., Black, R.W., Tesoriero, A.J., and Haggland, A.L., 2000, Water quality in the Puget Sound Basin, Washington and British Columbia, 1996-98: U.S. Geological Survey Circular 1216, 31 p.

Fewtrell, Lorna, 2004, Drinking-water nitrate, methemoglobinemia, and global burden of disease-A discussion: Environmental Health Perspectives, v. 112, no. 14, p. 1371-1374.

Frans, L.M., 2000, Estimating the probability of elevated nitrate $(\mathrm{NO} 2+\mathrm{NO} 3-\mathrm{N})$ concentrations in ground water in the Columbia Basin Ground Water Management Area, Washington: U.S. Geological Survey Water-Resources Investigations Report 00-4110, 24 p.

GeoLytics, Inc., 2001, Census CD 2000 short form blocks, 2000 census of population and housing: GeoLytics, Inc., [CD-ROM], East Brunswick, N.J.

Gurdak, J.J., and Qi, S.L., 2006, Vulnerability of recently recharged ground water in the High Plains Aquifer to nitrate contamination: U.S. Geological Survey Scientific Investigations Report 2006-5050, 39 p. 
Helsel, D.R., and Hirsch, R.M., 1992, Statistical methods in water resources: New York, Elsevier Science Publishing Company, Inc., 522 p., 1 diskette, accessed January 23, 2008, at http://pubs.usgs.gov/twri/twri4a3/

Hosmer, D.W., and Lemeshow, Stanley, 1989, Applied logistic regression: New York, John Wiley \& Sons, Inc., 375 p.

Jones, M.A., Vaccaro, J.J., and Watkins, A.M., 2006, Hydrogeologic framework of sedimentary deposits in six structural basins, Yakima River Basin, Washington: U.S. Geological Survey Scientific Investigations Report 2006-5116, 24 p.

Menard, Scott, 2002, Applied logistic regression analysis (2nd ed.): Thousand Oaks, Calif., Sage Publications, Inc., $128 \mathrm{p}$.

National Research Council, 1993, Ground water vulnerability assessment, contamination potential under conditions of uncertainty: National Academy Press, Washington, D.C., 210 p., accessed December 5, 2007, at http://books.nap.edu/openbook.php?isbn=0309047994

Nolan, B.T., and Clark, M.L., 1997, Selenium in irrigated agricultural areas of the western United States: Journal of Environmental Quality, v. 26, no. 3, p. 849-857.

Nolan, B.T., Hitt, K.J., and Ruddy, B.C., 2002, Probability of nitrate contamination of recently recharged groundwaters in the conterminous United States: Environmental Science \& Technology, v. 36, no. 10, p. 2138-2145.

Nolan, B.T., Ruddy, B.C., Hitt, K.J., and Helsel, D.R., 1998, A National look at nitrate contamination in ground water: Water Conditioning and Purification, v. 39, no. 12, p. 76-79.

Price, Curtis, Nakagaki, Naomi, Hitt, Kerie, and Clawges, Rick, 2003, Mining GIRAS-Improving on a national treasure of land use data, in Proceedings of the 23rd ESRI International Users Conference, July 7-11, 2003: Redlands, Calif., 11 p.

Ruddy, B.C., Lorenz, D.L., and Mueller, D.K., 2006, Countylevel estimates of nutrient inputs to the land surface of the conterminous United States, 1982-2001: U.S. Geological Survey Scientific Investigations Report 2006-5012, 17 p.

Rupert, M.G., 2003, Probability of detecting atrazine/ desethyl-atrazine and elevated concentrations of nitrate in ground water in Colorado: U.S. Geological Survey WaterResources Investigations Report 02-4269, 35 p.

SAS Institute, 1990, SAS/STAT user's guide: Cary, NC., SAS Institute, Inc., 1,686 p.

Schwarz, G.E., and Alexander, R.B., 1995, State Soil Geographic (STATSGO) data base for the conterminous United States: U.S. Geological Survey Open-File Report 95-449, accessed March 10, 2001, at http://water.usgs.gov/lookup/getspatial?ussoils
Spatial Climate Analysis Service-Oregon State University, 2006: Oregon Climate Service, accessed January 19, 2006, at http://www.ocs.orst.edu/prism/

SPSS, Inc., 2000, SYSTAT 10, Statistics I-Software documentation: Chicago, Ill., SPSS Inc., 663 p.

Tesoriero, A.J., Inkpen, E.L., and Voss, F.D., 1998, Assessing ground-water vulnerability using logistic regression: Source Water Assessment and Protection 1998 Conference Proceedings, Dallas, Texas, p. 157-165.

U.S. Census Bureau, 1991, Census of population and housing, 1990. Public Law 94-171 data (United States): U.S. Census Bureau, Washington, D.C., [CD-ROM]

U.S. Department of Agriculture, 1993, Soil survey manual: U.S. Department of Agriculture, Handbook no. 18, 437 p.

Vogelmann, J.E., Howard, S.M., Yang, Limin, Larson, C.R., Wylie, B.K., and Van Driel, Nick, 2001, Completion of the 1990s National Land Cover Dataset for the conterminous United States from Landsat Thematic Mapper data and ancillary data sources: Photogrammetric Engineering and Remote Sensing, v. 67, no. 6, p. 650-652.

Ward, M.H., Mark, S.D., Cantor, K.P., Weisenburger, D.D., Correa-Villase, Adolofo, and Zahm, S.H., 1996, Drinking water nitrate and risk of non-Hodgkin's lymphoma: Epidemiology v. 7, no. 5, p. 465-471.

Washington Department of Natural Resources, 2005, Digital 1:100,000-scale geology of Washington State: Division of Geology and Earth Resources, Washington State Department of Natural Resources Open-File Report 2005-3, accessed December 5, 2007, at http://www.dnr.wa.gov/geology/dig100k.htm

Weyer, Peter, Cerhan, J.R., Kross, B.C., Hallberg, G.R., Kantamneni, Jiji, Breuer, George, Jones, M.P., Zheng, Wei, and Lynch, C.F., 2001, Municipal drinking water nitrate level and cancer risk in older women: The Iowa Women's Health Study, Epidemiology, v. 11, p. 327-338.

Williamson, A.K., Munn, M.D., Ryker, S.J., Wagner, R.J., Ebbert, J.C., and Vanderpool, A.M., 1998, Water quality in the central Columbia Plateau, Washington and Idaho, 1992-1995: U.S. Geological Survey Circular 1144, 35 p.

Wolock, D.M., 1997, STATSGO soil characteristics for the conterminous United States: U.S. Geological Survey OpenFile Report 97-656, 200 p.

Wolock, D.M., 2003, Estimated mean annual natural ground-water recharge in the conterminous United States: U.S. Geological Survey Open-File Report 2003-311, digital data set available at http://water.usgs.gov/lookup/ getspatial?rech48grd 
22 Estimating the Probability of Elevated Nitrate Concentrations in Ground Water in Washington State

This page intentionally left blank. 
Manuscript approved for publication, February 22, 2008

Prepared by the USGS Publishing Network,

Bob Crist

Bill Gibbs

Lyn Osburn

Bobbie Jo Richey

Linda Rogers

Sharon Wahlstrom

For more information concerning the research in this report, contact the Director, Washington Water Science Center

U.S. Geological Survey, 934 Broadway - Suite 300

Tacoma, Washington 98402

http://wa.water.usgs.gov 


\section{总}

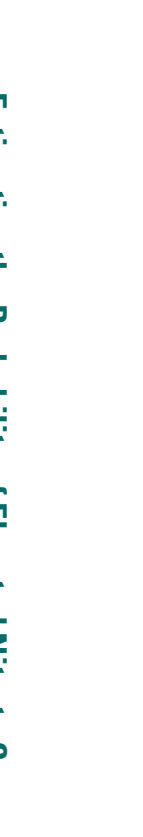

